\title{
Förundran och gåtfullhet
}

\author{
Af Bosse Bergstedt
}

Rodfastet universalisme. N.F.S Grundtvigs poesi, menneskesyn, kultursyn och skolesyn. Red. Lilian Zøllner, oversattelse Anna Marie Andersen, 225 kr. Vejle 1996.

Efter att ha läst boken Rodfastet universalisme som har sammanställts av Lilian Zøllner, så är det en fråga som stannar kvar hos mig, den ställs i den inledande artikeln av Anne-Marie Steen Petersen och den lyder; vad var det? En septemberdag hade hon rest med bussen förbi Grundtvigs Kirke och plötsligt förundrats över vad hon upplevde. Något stort, en byggnad, något massivt och samtidigt andligt, något märkligt. När hon vänder sig om för att se vad det var så kan hon inte se något mera än låga gula hus.

Denna upplevelse är början på en kunskapsresa. Anna-Marie Steen Petersen söker sig till böcker, fotografier, hon tänker och drömmer om Grundtvigs Kirke. Hon vänder tillbaka flera gånger, gör nya upptäckter men behåller hela tiden en förundran inför det som möter henne. Den märkliga kyrkan får förbli en gåta som man kan närma sig från olika håll men som aldrig helt och hållet går att lösa. Förundran lever vidare och mitt i detta förhållningssätt lever också Grundtvig vidare.

Om man vill skriva om Grundtvigs tankar och texter gäller det att bevara en förundran och en gåtfullhet. Tyvärr har det under årens lopp varit många som glömt detta och istället inordnat Grundtvigs idéer i bestämda kategorier eller tankesystem. Viljan att förstå och förklara blir då till en återvändsgränd som missar själva poängen.

Den 8 september 1996 var det 75 år sedan man påbörjade arbetet med Grundtvigs Kirke på Bispebjerg Bakke. När Köpenhamn 1996 var Europas kulturhuvudstad så inbjöds det till ett internationellt seminarium om Grundtvigs poesi, människosyn, kultursyn och skolsyn. Seminariet fick titeln Rodfeestet Universalisme och det fick också den bok som med olika artiklar följer upp seminariets olika teman.

Ett vanligt sätt att beskriva Grundtvigs tankar är att jämföra dem med någon annan stor tänkare. I Rotfastet universalisme görs flera sådana jämförelser. Arthur Mcdonald Allchin drar paralleller med den polsk-amerikanske författaren Czeslaw Milosz medan Håkan Eilert jämför Grundtvig med Konfucius. Det är intressanta artiklar som tar läsaren med till helt skilda historiska epoker. Allchin tar sin utgångspunkt i växelverkan mellan förnuft och känsla, det är en central tanke hos Grundtvig att dessa två skall växelverka. Allchin skriver också om språkets och ordens betydelse för att föra historien vidare. Han hänvisar till att Milosz har berömt Carl von Linné för hans arbete med att namnge olika arter i naturen. »Ord holder længere, skønt de ikke er evige, og 
de kan give længere liv til de arter, de betegner.« Men att sätta ord på saker och ting kan göras på flera olika sätt, Linnés vetenskapliga systemtänkande utestängde samtidigt en del av det gåtfulla och märkliga. Just detta var något som Grundtvig vände sig emot, han sökte de ord som kunde bevara såväl förnuft som känsla. Han vände sig därför i första hand till poesi och myter, där fanns den nödvändiga dubbelhet som kunde påminna människan om livsgåtan. Att Grundtvig lyckas förena såväl det individuella som det nationella beror på att han aldrig släpper det märkliga och underliga. Här finns det helt klart paralleller till Milosz men säkert också till de flesta av modernismens författare.

En av vår tids största tänkare Jacques Derrida anses ha hämtat en hel del inspiration i kinesisk filosofi. Här finns tydliga inslag av motsatsernas spel, vilka föregår utan någon yttre inverkande kraft. Att »fullända sin Tao« innebär att bli en del av den ständigt pågående växelverkan mellan tillvarons två motpoler. Visst finns det hos Grundtvig en bejakelse av livet som erinrar om en konfuciansk åskådning men det finns också tydliga skillnader. Grundtvigs tänkande bryter fram i en tid när den moderna individen håller på att "födas«. Självmedvetandet blir i allt högre grad till individualism. Att så inte är fallet $\mathrm{i}$ Japan belyser en annan av bokens artiklar, »N.F.S. Grundtvigs tankar og Japan«. Där beskriver Hajime Yano dagens Japan som ett samhälle som fortfarande är kollektivistisk men där det finns allt större behov av en individualism.

Trots dessa olikheter så väcker Håkan Eilerts artikel många nya funderingar. Det finns helt tydligt ett samband mellan centrala inslag i österländskt tänkande och Grundtvigs ständiga strävan efter växelverkan och spel mellan tillvarons motsatser.

Ännu ett sätt att närma sig Grundtvigs tänkande är att se vad det fått för genomslag runt omkring $\mathrm{i}$ världen. Det går att jämföra Grundtvigs begrepp »folkelighed « med vår tids diskussion om det civila samhället, vilket görs av Bernd Henningsen i artikeln »Demokratiet i et Europa i forandring «. Liknande utgångspunkter görs av Dmitri Gaura som pekar på den stora betydelse som Grundtvig kan komma att få i uppbyggandet av den ryska kulturen. I Ryssland kan folkhögskolor tillsammans med andra utbildnings- och kulturinstitutioner medverka till man kommer ut ur en djupgående samhällskris och istället skapar civil enighed och en stärkt kulturell identitet. Den nya människan bygger på spontan känsla av mänsklig gemenskap och frihet, det är en människa som fritt och självständigt kan göra sina val och lita på sin egen kraft. En människa som söker en ny andlighet, är det vad som väntar eller redan existerar i det senmoderna västerländska samhället?

I ett stort projekt på Nornesalen har Lilian Zøllner under flera år kartlagt Grundtvigs skoltankar utanför Danmark och Norden. Av denna forskning framgår det tydligt att de länder som intresserat sig för Grundtvig har flera gemensamma kännetecken. Oavsett om det gäller Japan, Kina, Filippinerna eller Israel så handlar det om befolkningsgrupper som stått inför en omfattande 
kulturell förändringsprocess. I nästan varje land har det funnits ett skolsystem som kännetecknats av bokkunskap och ett elitinriktat utbildningssystem. Det har varit de mest utbildade och välmående som fattat de mest avgörande besluten, på folkets bekostnad. Ett fjärde kännetecken är att det har varit enskilda personer som tagit initiativ till att starta folkhögskolor i Grundtvigs anda. Inte helt oväntat har de historiska och sociologiska omständigheterna stor betydelse för upprättandet av folkhögskolor.

Artiklarna i Rodfastet universalisme ger en bred bild av hur Grundtvigs tänkande kan jämföras såväl med författare och filosofer som med skapandet av nya folkhögskolor runt hela världen. Detta är både intressant och viktigt men frågan är om det fördjupar förståelsen för Grundtvigs tänkande? Är det inte i stället så att alla dessa jämförelser kan medföra att Grundtvigs egna texter utvattnas och glöms bort? Vad händer då med det förunderliga, märkliga och gåtfulla? Kanske är det betydligt mera värdefullt att återvända till Grundtvig själv, att nyläsa hans texter med vår tids ögon. Och om man nu nödvändigtvis skall göra jämförelser så bör man inrikta sig på samtida texter, den danska romantiken bör kartläggas genom en samläsning av samtida verk, $t$ ex Oehlenschläger och Kierkegaard. Samspelet är oerhört mycket mer intressant än reproduktionen och därför skulle det också vara värdefullt att se Grundtvig parallelt med namn som Blake, Wordsworth, Coleridge, Keats, Carlyle, Emerson och Yeats. Men kanske viktigast av allt, varje jämförelse och alla paralleller måste bevara gåtan och förundran, »vad var det?» 